\title{
Effect of Varietal Replacement Demonstration on the Yield and Economics of Turmeric (Curcuma longa) cv. Rajendra Sonia in Bhagalpur District of Bihar, India
}

\author{
Kamal Kant ${ }^{1}$, Ghanshyam², S. K. Gupta ${ }^{3}$, S. K. Pathak ${ }^{4}$, A. B. Patel ${ }^{3}$ Sanoj Kumar $^{5}$, \\ Amit Kumar $^{6}$, R. Vishwakarma ${ }^{3,8}$ and R. K. Sohane ${ }^{8}$ \\ ${ }^{1}$ Department of Horticulture, ${ }^{2}$ Department of Soil Science \& Agricultural Chemistry, \\ ${ }^{3}$ Department of Agronomy, ${ }^{5}$ Department of Agricultural Engineering, ${ }^{6}$ Department of Animal \\ Husbandry, ${ }^{8}$ Department of Agricultural Entomology, \\ ${ }^{8}$ Director Extension Education, Bihar Agricultural University, Sabour, \\ Bhagalpur, Bihar, India \\ *Corresponding author
}

\section{Keywords \\ spice crops agro-climatic soil fertility weather conditions}

\section{Article Info}

Accepted: 08 January 2020 Available Online: 10 February 2020

\section{A B S T R A C T}

Turmeric(Curcuma longa) is one of the important spice crops grown for fresh and processing purpose all over the India due to its wider adaptability under various agroclimatic conditions, which plays a major role in supplementing the income of small and marginal farmer of the Bhagalpur district of Bihar state. The present study was carried out atGoradih\&Pirpainti block of Bhagalpur district during kharif 2017-18 and 2018-19. Varietal replacement through Farmer FIRST Project were conducted on turmeric by the active participation of the farmers with the objective of improved technologies of turmeric production potential. The improved technologies consist improved variety (Rajendra Sonia), balanced fertilizers (Soil test based) application and integrated pest and disease management, etc. The development of the agriculture is primarily depends on the application of the scientific technologies by making the best use of available resources. One of the major constraints of traditional turmeric farming is low productivity because of non-adoption of advanced technologies like improved varieties. To increase the production, productivity and quality of agricultural produce, varietal replacement are being conducted at various farmer's field. All the recommended practices were provided to the selected farmers. The data related to the cost of cultivation, production, productivity, gross return and net return were collected as per schedule and analysed. Result of the present study revealed the higher average yield in the varietal replacement demonstration was recorded $(254.61 \mathrm{q} / \mathrm{ha})$ as compared to farmers practice $(125.20 \mathrm{q} / \mathrm{ha})$ traditional adopted by the farmers. The percentage increase in the yield over farmer's 103.35 was recorded. The technology gap and extension gap were computed 145.39and 129.40q/ha respectively, along with 36.34 percent of technology index. The varietal replacement demonstration field gave higher average net return Rs. 653001.00 and B:C ratio is 1:2.74. The result of the study indicated the gap existed in the potential yield and demonstration yield is due to soil fertility and weather conditions. Present result clearly show that the yield and economics of turmeric can be boost up by adopting recommended technologies. 


\section{Introduction}

Turmeric (Cucurma longa) is a traditional crop with a long history of cultivation in Asia and the Pacific. It is widely used as a spice vegetable in India, whereas, it is very closely associated with culture in many of the South Pacific Islands. It ranks fourth after cassava and yam, in terms of total production, area and consumption (Poonia and Pithia 2011). turmeric also known as Haldiis a tropical spice crop which is part of the ginger family of herbs, the Zingiberaceae. Turmeric is believed to have originated in India, perhaps in Eastern India or Malaysia (Sturlevant, 1919).

All parts of the plant including rhizome, is edible and contain abundant starch (Bose et al., 2012). Turmeric is a rich source of major components of the diet viz. proteins, minerals and vitamins. The nutritional value of a food depends upon its nutritional contents, digestibility and the presence or absence of anti-nutrients or toxic factors. Several authors have evaluated the chemical composition of whole corms and cormels of turmeric (Surjit and Tarafdar, 2015).

It has been observed that in spite of the fact that turmeric are neglected crops, their nutritional value is high. Apart from the low fat content, the crop is nutritionally superior to other spices in protein, mineral and vitamin contents (Onwueme, 1978). Investigation have shown that turmericcontains digestible starch, protein of good quality, vitamin C, thiamine, riboflavin, niacin and high scores of proteins and essential amino acids.

The crop is also very rich in dietary fibre, thus, it could be employed in the treatment of diseases such as obesity, diabetes, cancer and gastrointestinal disorders (Mukherjee et al., 2016). Turmeric is cultivated in an area of around $238 \mathrm{~m}$ ha with an annual production of 1133 MT (NHB Database, 2018) and the major turmeric growing states are Assam, Bihar, Nagaland, Manipur, Orissa, Maharashtra, Kerala, Andhra Pradesh, Meghalaya, West Bengal, Uttar Pradesh, Gujarat and Tamil Nadu. In Bihar state total area under turmeric is 2.40 thousand ha with a production of 2.60 thousand tonnes (NHB Database, 2016).

Turmeric is mainly grown as a major spice crop in north Bihar areas like Muzaffarpur, Samastipur, Vaishali, East Chaparan, Madhubani, Shitamarhi, Bhagalpur and Begusarai districts in Bihar. Despite of the importance of this crop, its cultivation anywhere in India is generally a subsistent to semi-commercial crop due to low productivity because of non-adoption of advanced technologies like improved varieties.

To increase the production, productivity and quality of agricultural produce, varietal replacement demonstrations are being conducted at project area various farmers' field.

\section{Materials and Methods}

The varietal replacement demonstration is an applied approach to accelerate the dissemination of proven technologies at project area farmer's fields in a full package and practice mode with an objective to explore the maximum available resources of crop production and also to bridge the productivity gaps by enhancing the production in national basket (Choudhary et al., 2018).

To overcome the problems faced by the farmers in cultivation of turmeric, integrated crop management in turmeric was conducted by Farmers FIRST Project, Bihar Agricultural University, Sabour, Bhagalpur during Kharif 2017-18 and 2018-19 in five farmers of Bhagalpur district. In the demonstration, 
improved variety Rajendra Sonia was grown in 0.5 ha area each farmer with integrated crop management practices and the farmers practice traditionally in 0.5 ha area for comparison. The integrated crop management practices consisting the conjoint use $20 \mathrm{t} / \mathrm{ha}$ FYM with a balanced fertilization of 100:60:80 NPK kg/ha.

Improved variety of turmeric i.e. Rajendra Sonia introduced under demonstration was released from a local selection from Dholi, Muzaffarpur area of Bihar is able to yield 400-450q/ ha. The rhizomeis non-acrid, wellshaped and generally devoid of fingers or propagules. Treated with fungicide namely, diathan M-45 and integrated pest management strategies were demonstration as per need.

Selection from local collections of Dholi, Muzaffarpur district, Average yield of 420q/ha, potential yield Bihar, released from Tirhut College of Agriculture, of $450 \mathrm{q} / \mathrm{ha}$, matures by 180-210 days Dholi, under the aegis of Tirhut College of Agriculture, Dholi, Muzaffarpur under Rajendra Prasad Central Agricultural University, Pusa, Samastipur, Bihar.

The Rajendra Sonia variety was a local selection. Salient features of technology are plant height upto $38-60 \mathrm{~cm}$, canopy spread upto35 $-52 \mathrm{~cm}$, pseudostem girth upto $11-$ $15 \mathrm{~cm}$, growth habit is erected, rhizome type stem, rhizome size $50-70$ gm suitable for culinary purpose due softness and non-acrid which make it easy to spices.

Responsive to recommended dose of fertilizer at both rainfed and irrigated conditions situation in Kharif and spring -summer season and field tolerant to pest and leaf blight disease with average yield of 254.61 $\mathrm{q} / \mathrm{ha}$ turmeric (Rajendra Sonia) may progressively commercialized in Bihar as well as in Jharkhand. The technological interventions followed in farmers practice and demonstration is given in table 1 .

Before initiating the demonstration, the beneficiary farmers were given with skill training on various technological interventions to be followed in turmeric cultivation. The performance of crop was periodically observed by the scientists of Farmers FIRST Project, Bihar Agricultural University, Sabour, Bhagalpur and advisory recommendations were followed.

During harvest, yield data was collected from both the demonstration and farmers practice. At the end, cost of cultivation, net income and cost benefit ratio were worked out. An average of cost of cultivation, yield and net returns of different farmers was analysed by the formula.

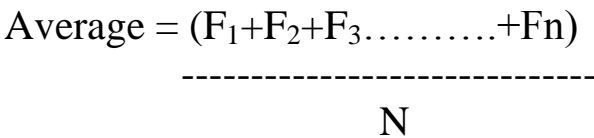

Where,

$\mathrm{F}=$ Farmer $(\mathrm{s})$

$\mathrm{N}=$ No. of farmers

In the present study, technology index was operationally defined as the technical feasibility obtained due to implementation of varietal replacement demonstrations in elephant foot yam. To estimate the technology gap, extension gap and technology index following formula used as given by Samui et al., 2000.

Technology Gap $=\mathrm{P}_{1}($ Potential yield $)-\mathrm{D}_{1}$ (Demonstration yield)

Extension Gap $=\mathrm{D}_{1}$ (Demonstration yield $)-$ $\mathrm{F}_{1}$ (Farmers yield)

Technology index $=\frac{\text { Potential yield }- \text { Demonstration yield }}{\text { Potential yield }}$ X 100 
$\mathrm{B}: \mathrm{C}$ ratio $=\frac{\text { Net income (Rs/ha) }}{\text { Cost of cultivation (Rs/ha) }}$

Percent increase over farmer's practices

Improved practices - Farmers practices

= ----------------------------X 100

Farmers Practices
The economic indices depicted in table 2 showed that the average yield of turmeric variety (Rajendra Sonia) were $254.61 \mathrm{q} / \mathrm{ha}$ and 255.55q/ha during kharif 2017-18 and 201819 respectively under demonstrated technology however, under farmer's practices the average yield were found to be $125.20 \mathrm{q} / \mathrm{ha}$ and $126.88 \mathrm{q} / \mathrm{ha}$ during respective years. The average percent increases over local yield were 103.35 .

Table.1

\begin{tabular}{|c|c|c|c|c|}
\hline S.N. & $\begin{array}{l}\text { Package of practices } \\
\text { (Technology } \\
\text { intervention) }\end{array}$ & $\begin{array}{l}\text { Varietal replacement demonstration } \\
\text { (Recommended package of practices) }\end{array}$ & $\begin{array}{l}\text { Farmers } \\
\text { practice } \\
\text { (Local/check) }\end{array}$ & Gap \\
\hline 01. & Selection of variety & Improved variety (Rajendra Sonia) & Age old variety & Partial gap \\
\hline 02. & Soil testing & Have been done in all the location & Not in practice & Full gap \\
\hline 03. & Seed rate & $18 \mathrm{q} / \mathrm{ha}$ & $18 \mathrm{q} / \mathrm{ha}$ & Partial gap \\
\hline 04. & Seed treatment & Seed treated with fungicide Dithan M-45 & Not done & Full gap \\
\hline 05. & Spacing & $70 \mathrm{~cm} \times 60 \mathrm{~cm}$ & $60 \mathrm{~cm} \times 50 \mathrm{~cm}$ & Partial gap \\
\hline 06. & $\begin{array}{lr}\text { Application } & \text { of } \\
\text { recommended } & \text { dose } \\
\text { of fertilizer } & \end{array}$ & $\begin{array}{l}100 \mathrm{~kg} \mathrm{~N}+60 \mathrm{~kg} \mathrm{P}_{2} \mathrm{O}_{5}+80 \mathrm{~kg} \mathrm{~K}_{2} \mathrm{O} \text { per ha } \\
(50 \% \mathrm{~N}+100 \% \mathrm{P} \mathrm{K} \text { at the time of planting and } \\
\text { remaining } 50 \% \mathrm{~N} \text { applied at } 40 \text { days and } 80 \\
\text { days after planting) }\end{array}$ & $\begin{array}{l}\text { Imbalance and } \\
\text { inadequate }\end{array}$ & Partial gap \\
\hline 07. & $\begin{array}{l}\text { Application of } \\
\text { vegetable special } \\
\text { (micro-nutritional) } \\
\text { Irrigation }\end{array}$ & $\begin{array}{l}\text { Foliar spray of vegetable special (micro- } \\
\text { nutrients) } 75 \mathrm{~g}+15 \text { lit water }+ \text { lemon }+1 \\
\text { shampoo (Rs. 1). }\end{array}$ & $\begin{array}{l}\text { Not applied any } \\
\text { micro-nutrient }\end{array}$ & Full gap \\
\hline 08. & Irrigation & $\begin{array}{l}\text { Drip or furrow method of irrigation at once in a } \\
7-11 \text { days interval depend upon soil condition }\end{array}$ & $\begin{array}{l}\text { Twice in a } \\
\text { month }\end{array}$ & Partial gap \\
\hline 09. & Weed management & $\begin{array}{l}\text { Pre-emergence herbicide pendimethalin @ } 1.5 \\
\mathrm{~kg} \text { a.i/ha, followed by hand weeding depend } \\
\text { upon weed intensity. }\end{array}$ & $\begin{array}{l}\text { Weeding is not } \\
\text { common }\end{array}$ & Partial gap \\
\hline 10. & $\begin{array}{l}\text { Plant protection } \\
\text { measures for control } \\
\text { of insect pest and } \\
\text { diseases }\end{array}$ & $\begin{array}{l}\text { Need based application for control: Aphid and } \\
\text { sucking pest-spraying with diamethoate ( } 30 \mathrm{EC}) \\
1.5 \mathrm{ml} / \mathrm{L} \text { of water. Leaf eating catterpiller: spray } \\
\mathrm{NPV}(250 \mathrm{LE} / \mathrm{ha}) \text {. Blight, pyithium rot \& leaf } \\
\text { blight }- \text { Spraying of (COC) blitox } 50- \\
3 \mathrm{~g} / \mathrm{L} \text { of water }\end{array}$ & $\begin{array}{l}\text { Plant protection } \\
\text { is not common }\end{array}$ & Partial gap \\
\hline 11. & Harvesting & Manual & Manual & No gap \\
\hline
\end{tabular}




\section{Results and Discussions}

The results clearly indicated the positive effect of varietal replacement demonstration over the existing practices toward enhancing the yield of elephant foot yam in the study area due to use of high yielding variety, timely sowing, balance dose of fertilizers, proper and timely irrigation, need based plant protection etc. The result is in conformity with the finding of Tiwari and Saxena (2001) and Tiwari et al., (2003). Yield of the varietal replacement demonstration and potential yield of the crop was compared to estimate the yield gaps which were further categorized into technology and extension gap.

The data of table 3 depicted the technology gap in the demonstration yield against potential yield which is $145.39 \mathrm{q} / \mathrm{ah}$ during both the year and reflects the farmer's cooperation in carrying out such demonstrations with encouraging results in subsequent years.

Table.2 Economics of varietal replacement demonstration of year 2017-18 and 2018-19

\begin{tabular}{|c|c|c|c|c|c|c|c|c|c|c|c|c|c|c|c|}
\hline Variables & & Id $(q$ & & & $\begin{array}{l}\text { ost } \\
\text { tivat } \\
\text { Rs./h }\end{array}$ & & & ss re & & & ret & & & 16 & \\
\hline$\stackrel{\bar{\Xi}}{\grave{\nexists}}$ & $\frac{\infty}{\frac{\infty}{1}}$ & $\frac{\overrightarrow{0}}{\stackrel{0}{\vec{~}}}$ & 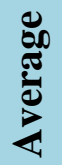 & $\frac{\infty}{\frac{1}{n}}$ & 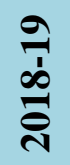 & 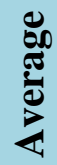 & $\frac{\infty}{\frac{1}{5}}$ & 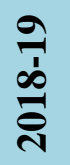 & 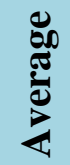 & $\frac{\infty}{\frac{\infty}{n}}$ & 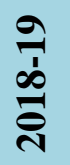 & 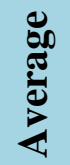 & $\frac{\infty}{\frac{1}{3}}$ & $\frac{\text { oे }}{\vec{\sigma}}$ & 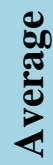 \\
\hline $\begin{array}{l}\text { Farmers } \\
\text { practice }\end{array}$ & $\begin{array}{l}\tilde{n} \\
\tilde{n} \\
\end{array}$ & $\begin{array}{l}\infty \\
\infty \\
\stackrel{0}{0} \\
\end{array}$ & ণิ & $\begin{array}{l}\underset{8}{0} \\
\stackrel{\infty}{\oplus} \\
\stackrel{n}{n}\end{array}$ & 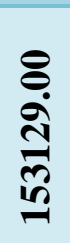 & 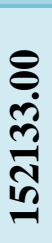 & 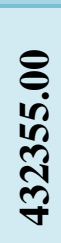 & $\begin{array}{l}\stackrel{8}{8} \\
\stackrel{8}{\circ} \\
\stackrel{8}{+}\end{array}$ & 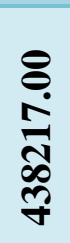 & 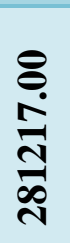 & 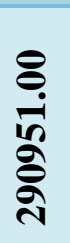 & 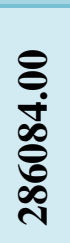 & 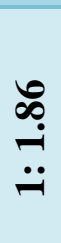 & 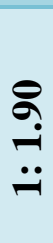 & 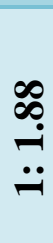 \\
\hline $\begin{array}{c}\text { Recommended } \\
\text { practices } \\
\text { (Rajendra } \\
\text { Sonia) }\end{array}$ & $\begin{array}{l}\infty \\
\text { ஸे } \\
\text { ஸे }\end{array}$ & 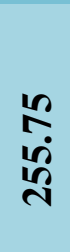 & 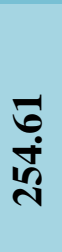 & 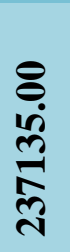 & 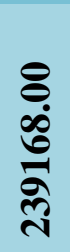 & 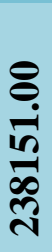 & $\underset{\infty}{\stackrel{8}{\infty}}$ & $\begin{array}{c}\frac{8}{10} \\
\frac{1}{10} \\
\infty\end{array}$ & 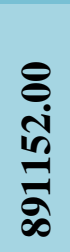 & $\begin{array}{l}8 \\
8 \\
10 \\
8 \\
8 \\
6 \\
6\end{array}$ & 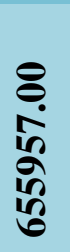 & 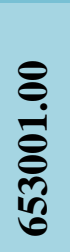 & $\underset{\stackrel{N}{N}}{\stackrel{\Delta}{ت}}$ & $\begin{array}{l}\underset{\sim}{\Delta} \\
\stackrel{-}{\sim}\end{array}$ & $\begin{array}{l}\stackrel{\mathbb{N}}{\mathrm{i}} \\
\stackrel{-}{\sim}\end{array}$ \\
\hline
\end{tabular}

Table.3 Yield technology gap and technology index of varietal replacement demonstration

\begin{tabular}{|c|c|c|c|c|c|}
\hline Variables & Yield (q/ha) & $\begin{array}{c}\text { Increase (\%) } \\
\text { over farmers } \\
\text { Practice }\end{array}$ & $\begin{array}{c}\text { Technology } \\
\text { gap (q/ha) }\end{array}$ & $\begin{array}{c}\text { Extension } \\
\text { gap (q/ha) }\end{array}$ & $\begin{array}{c}\text { Technology } \\
\text { index (\%) }\end{array}$ \\
\hline Farmers Practice & 125.20 & - & - & - & - \\
\hline $\begin{array}{c}\text { Recommended } \\
\text { practices } \\
\text { (Rajendra Sonia) }\end{array}$ & 254.61 & 103.35 & 145.39 & 129.40 & 36.34 \\
\hline
\end{tabular}


The technology gap observed may be attributing to the dissimilarity in soil fertility status, timely sowing and weather conditions. Similar finding was recorded by Mitra and Samjdar (2010). Further, the higher extension gap was observed. The extension gap ranged from $129.40 \mathrm{q} / \mathrm{ha}$ during the period of study that emphasizes the need to educate the farmers through various means for adoption of improved production technologies to mitigate the extension gap.

The data of table 2 reveals that as far as average economics of turmeric is concerned; gross cost, net income and benefit cost ration were Rs. 887180.00 /ha, Rs.650045.00 /ha and 1: 2.74, respectively during 2017-18 and Rs.895125.00 /ha, Rs.891152.00 /ha and 1: 2.74, respectively during 2018-19 under demonstration plot.

However, Rs.432355.00 /ha gross cost, Rs.281217.00 /ha net return with 1: 1.86 . benefit cost ration during 2017-18 and Rs.444080.00 /ha gross cost, Rs.290951.00 /ha net return with 1: 1.90. Benefit cost ratio observed during 2018-19 under farmer's practice.

The superiority of recommended package of practices under varietal replacement demonstration over farmer's practice was also reported by Mitra and Samajdar (2010) and Balai et al., (2012). From the finding of present study, it can be concluded that use of above prescribed technologies of turmeric cultivation can reduce the technology gap to a considerable extent resulting in to increased productivity as well as quality in Bihar.

It requires collaborative extension efforts to enhance adoption level of location and crop specific technologies among of the farmers for bridging these gaps. Therefore, extension agencies in the district need to provide proper technical support to the farmers through various educational and extension methods for better turmeric production in Bhagalpur districts of Bihar.

\section{References}

Balai, C.M., Meena, R.P., Meena, B.L. and Bairwa, R.K. (2012). Impact of frontline on rapeseed and mustard yield improvement. Indian Res.J.ofExtn Edu., 12(2): 113-116.

Bose, T.K., Kabir, J. Maity, T.K. Parthasarathy, V.A. and Som, M.G., (2003). Vegetable crops, vol 2. Naya Udyog Publishers, Kolkata. Pp: 413442.

Chaudhary, R.P., Choudhary, G.K., Prasad, R., Singh, R. and Chaturvedi, A.K. (2018). Impact assessment of front line demonstration on mustard crop. Int.J.Curr.MicrobiologyApp.Sci.(7): 4737-4742.

Henry, R.J. (2001). Plant genotyping: The DNA fingerprinting of plants. $C A B$ Publishing, Southern Cross University, Australia.

Jeengar, K.L., Panwar, P.P. and Pareek, O.P. (2006). Front line demonstration on maize in Bhilwara district of Rajasthan. Current Agric., (30): 115-116.

Markam, S.K., Sahu, B., Thakur, C.L. and Gour, A.R. (2019). Impact of front line demonstrations on the yield and economics of Colocasia (Colocasia esculanta var. antiquorum L.Scott.) in Kanker District of Chhattisgarh. Int. J. Curr. Microbial. App. Sci. 8(12): 14001406.

Mitra, B. and Samajdar, T. (2010). Field gap analysis of rapeseed-mustard through front line demonstration. Agricultural Extension Review, (22): 16-17.

Mukherjee, D. Roquib, Md. A., Das, N.D. and Mukherjee, S. (2006). A study on genetic variability, character association and path co-efficient analysis on 
morphological and yield attributing characters of taro (Colocasia esculanta var. antiquorum L.Scott.). American Journal of Plant Sciences. 7: 479-488.

NHB Database, (2016).

NHB Database, (2018).

Onwurme, I.C. (1978). The tropical tuber crops: yams, cassava, sweet potato, cocoyams. John Wiley and Sons, New York.

Poonia, T.C. and Pithia, M.S. (2011). Impact of front line demonstrations of chickpea in Gujarat. Legume Research, 34(4): 304-307.

Samui, S.K., Mitra, S., Roy, D.K., Mondal, A.K. and Saha, D. (2000). Evaluation of front line demonstration on groundnut (Arachis hypogea L.) in Sundarbans. J. of Indian Society of Coastal Agri. Res. 18(2): 180-183.
Sturlevant, E.L., (1919). Note on edible plants. Res. N.Y. Agric. Expt. Stn. 69(70): 185-186.

Surjit, M. and Tarafdar, J. (2015). Diversity in Morpho-Biometrical characters, Nutritional facts and Isozymes activity of Indian landraces of upland Taro (Colocasia esculanta var. antiquorum L.Scott.). International Journal of Tropical Agriculture, 33(2): 1163-1166.

Suryawanshi, S.D. and Prakash, M. (1993).

Impact of viable technology of promoting oil seeds in Maharashtra. Indian J. Agri. Econ., 48(420): 102-106.

Tiwari, K.B. and Saxena, A. (2001). Economic analysis of FLD of oilseed in Chhindwara. Bhartiy Krishi Anusandhan Patrika, 16(3\&4): 185189.

\section{How to cite this article:}

Kamal Kant, Ghanshyam, S. K. Gupta, S. K. Pathak, A. B. Patel, Sanoj Kumar, Amit Kumar, R. Vishwakarma and Sohane. R. K. 2020. Effect of Varietal Replacement Demonstration on the Yield and Economics of Turmeric (Curcuma longa) cv. Rajendra Sonia in Bhagalpur District of Bihar. Int.J.Curr.Microbiol.App.Sci. 9(02): 1842-1848. doi: https://doi.org/10.20546/ijcmas.2020.902.210 